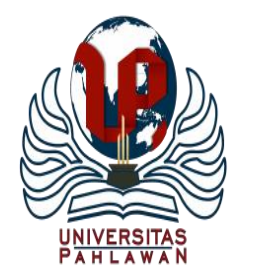

Edukatif : Jurnal Ilmu Pendidikan Volume 2 Nomor 2 Tahun 2020 Halm 170-175

EDUKATIF: JURNAL ILMU PENDIDIKAN

Research \& Learning in Education

https://edukatif.org/index.php/edukatif/index

\title{
Analisis Kebijakan terkait Standar Pembiayaan pada Pendidikan Dasar
}

\author{
Aprima Vista ${ }^{1}$, Ahmad Sabandi ${ }^{2}$ \\ Universitas Negeri Padang, Sumatera Barat, Indonesia ${ }^{1,2}$ \\ E-mail : $\underline{\text { Aprimavista14@gmail.com }} \underline{\text { sabandi@fip.unp.ac.id }}^{2}$
}

\begin{abstract}
Abstrak
Penelitian ini membahas tentang kebijakan biaya standar pada Satuan Pendidikan Dasar, setiap satuan pendidikan memerlukan biaya untuk melakukan program kegiatan, baik program yang sedang berjalan, program yang akan dijalankan atau program perencanaan yang akan datang. Biaya pendidikan memiliki aturan dan standar minimum dalam penggunaannya, biaya termasuk biaya modal, biaya operasional dan biaya pribadi. Kebijakan Pendidikan Standar Biaya Pendidikan Dasar berdasarkan pedoman teknis penggunaan biaya operasional di sekolah, sekolah berwenang untuk mengelola kebijakan biaya pendidikan dasar sesuai dengan standar yang dinyatakan dalam pedoman teknis pemanfaatan anggaran pembiayaan, dengan standar Dari bimbingan teknis, diharapkan setiap satuan pendidikan dapat memperoleh kebijakan anggaran pembiayaan yang tepat dan efisien untuk mencapai tujuan pendidikan.
\end{abstract}

Kata Kunci: pambiayaan pendidikan, sekolah dasar

\begin{abstract}
This study discusses about the policy of standard cost in Primary Education Unit, each education unit needs a cost to do the activity program, either the program that is running, program to run or future planning program. Education cost has a rule and minimum standard in usage, the cost includes capital cost, operational cost and personal cost. The Policy of Standard Cost Primary Education based on the technical guidance of the operational cost usage in the shool, the school authorizes to manage the policy of primary education cost according to the standard stated in the technical guidance of the financing budget utilization, by the standard of technical guidance, it is expected each education unit can get appropriate and efficient financing budget policy to reach education goals.
\end{abstract}

Keywords: standard education cost, primary education

Copyright (c) 2020 Aprima Vista, Ahmad Sabandi

$\triangle$ Corresponding author :

Address :

Email : Aprimavista14@gmail.com

ISSN 2656-8071 (Media Cetak)

Phone :

ISSN 2656-8063 (Media Online)

DOI: 10.31004/edukatif.v2i2.126 


\section{PENDAHULUAN}

Adanya lembaga pendidikan mulai dari jenjang pendidikan usia dini sampai pada tahap perguruan tinggi, memberikan kesempatan kepada seluruh warga negara Indonesia untuk mendapatkan hak pendidikan secara layak, proses pendidikan berperan penting dalam meningkatkan sumber daya manusia yang unggul dan berkualitas,membentuk individu yang beriman dan bertaqwa kepada Tuhan Yang Maha Esa, serta berbudi pekerti yang luhur, berahklak mulia dalam rangka mencerdaskan kehidupan bangsa. Salah satu faktor kemajuan suatu bangsa adalah keunggulan sumber daya manusianya. Sumber daya manusia yang handal, dapat diperoleh dari pendidikan yang unggul dan berkualitas, adanya pendidikan memberikan kontribusi yang besar terhadap kemajuan, kemakmuran, dan kejayaan suatu bangsa.

Melalui pendidikan akan melahirkan generasi cerdas yang memiliki paradigma yang maju untuk mengembangkan pengetahuan dan keterampilannya,sesuai dengan Undang-undang Dasar 1945 yakni tujuan bangsa Indonesia adalah mencerdaskan generasi penerus bangsa, dalam hal ini dapat diartikan melalui pendidikan diharapkan dapat melahirkan generasi cerdas dan unggul yang akan membangun perkembangan dan kemajuan bangsa dan negara. Dalam hal ini sekolah merupakan sarana dalam kegiatan proses pendidikan, sebagai salah satu sarana pendidikan pihak sekolah perlu memperhatikan unsur-unsur pokok yang mengacu pada standar pendidikan salah satu diantaranya adalah standar pembiayaan.
Dalam proses kegiatan pendidikan, pembiayaan memiliki peran penting untuk memperlancar kegiatan pendidikan, dengan adanya pembiayaan diharapkan kegiatan pendidikan dapat berjalan lancar tanpa hambatan, pembiayaan juga menjadi faktor penting dalam mencapai tujuan pendidikan, pendidikan yang unggul dan berkualitas tentu saja membutuhkan pembiayaan yang seimbang, pada PP No. 32 Tahun 2013 dirincikan mengenai besarnya pembiayaan pendidikan dalam jangka waktu satu tahun, dalam hal ini standar pembiayaan pendidikan beranjak pada sumber-sumber pendapatan serta penggunaannya yang digunakan sebagai pengelolaan pendidikan, pembiayaan digunakan untuk memperlancar semua program yang telah direncanakan, pihak sekolah selaku instansi pendidikan memiliki kewajiban memberikan pelayanan yang sebaik-baiknya kepada lembaga itu sendiri, maupun masyarakat, peran pembiayaan dapat meningkatkan pelayanan pendidikan menjadi lebih baik serta mencapai pendidikan yang bermutu dan berkualitas.(Yuliani, 2016).

\section{METODE PENELITIAN}

Artikel ini akan meninjau dari berbagai sudut pandang tentang issue, situasi, kebijakan yang masih diperdebatkan. Jenis metode peneitian ini adalah analisis kajian pustaka (literature research). Penelitian ini akan memaparkan terhadap analisis jurnal ilmiah yang korelasi dengan pembahasan yang sudah dipilih. Tahaptahap dalam metode penelitian ini adalah (1) memilih artikel, (2) mengumpulkan data awal, (3) tantangan dari topik, (4) mengumpulkan data pendukung, (5) menghasilkan kesimpulan dan rekomendasi outline. 


\section{HASIL DAN PEMBAHASAN PENELITIAN}

\section{Standar Pembiayaan Pendidikan}

Berbagai kegiatan pendidikan membutuhkan pembiayaan, setiap satuan pendidikan membutuhkan pembiayaan untuk melaksanakan program kegiatannya baik program kegiatan yang sedang dijalankan, program yang akan dijalankan serta perencanaan program masa mendatang, pembiayaan pendidikan memiliki aturan dan standarsasi minimum dalam penggunaanya, pembiayaan meliputi biaya modal, biaya pelaksanaan kegiatan,dan biaya personal.dalam Permendiknas No 41 Tahun 2007, berisi tentang pengaturan minimum biaya pendidikan, dalam pengaturan Permendiknas telah mengatur besarnya biaya dan standar biaya yang harus dikeluarkan oleh peserta didik baik biaya umum maupun biaya khusus.

Biaya pendidikan juga dapat diartikan sebagai segala pengeluaran yang digunakan untuk memperlancar kegiatan pendidikan baik berupa uang maupun bukan uang, pembiayaan pendidikan menjadi unsur penting dalam memperlancar proses kegiatan pendidikan, sehingga dalam penggunaanya perlu dipertimbangkan efisiensi dan efektifitasnya, hal ini dikarenakan pembiayaan pendidikan mengacu pada standar peraturan dalam penggunaanya, berdasarkan pengaturan standarisasi tersebut, pembiayaan pendidikan harus mempertimbangkan efisiensi dari pembiayaan yang digunakan, dengan demikian pembiayaan pendidikan dapat bermanfaat guna memajukan pendidikan, serta mencapai tujuan pendidikan yang diharapkan.

Dalam UUD Negara Republik Indonesia 1945 (Amandemen 1V) berbunyi, pemerintah wajib membiayai setiap warga negara yang mengikuti pendidikan dasar, penyelenggaraan pendidikan diharapkan dapat membentuk karakter anak bangsa, berbudi pekerti yang luhur, cerdas, cakap, dan kreatif, memiliki keterampilan, dan mencerdaskan kehidupan bangsa (Haris, 2016).

\section{Pendidikan Dasar}

Pendidikan dasar merupakan pendidikan awal untuk membentuk kepribadian peserta didik berkepribadian mulia, berbudi pekerti luhur, cerdas, santun, kreatif, dan memiliki rasa cinta dan bangga terhadap bangsa dan negara. Pendidikan dasar sebagai satuan pendidikan yang dibentuk berdasarkan lingkungan daerah serta keberagaman sosial dan budaya, usia masa sekolah dasar dimulai pada usia 7 tahun hingga menamatkan pendidikan dasar pada usia maksimal 13 tahun, pada taraf pendidikan Dasar anak mengenal dan mempelajari berbagai bidang ilmu, siswa dibimbing dalam pemecahan masalah, serta dilibatkan dalam kegiatan pembelajaran yang mengembangkan keaktifan siswa untuk menggali pemahaman dan pengalamannya, mengenal diri dan lingkungannya, baik melalui kegiatan didalam maupun diluar kelas. Dalam Undang- Undang Nomor 20 Tahun 2001, menjelaskan tentang Sistem Pendidikan Nasional ,membahas tentang kajian Pendidikan Dasar bahwa pendidikan dasar merupakan jenjang pendidikan yang menjadi pondasi untuk melanjutkan kejenjang pendidikan tingkat menengah pertama. Hal penting yang menjadi tujuan dari pendidikan dasar adalah membekali peserta didik yang berbudi pekerti, cerdas, kreatif, mampu mengembangkan keterampilan yang diperolehnya untuk melanjutkan kejenjang pendidikan lanjutan tingkat pertama. Pendidikan 
dasar juga berperan sebagai pondasi untuk membentuk kepribadian siswa mengenal diri dan lingkungannya sehingga dapat menghasilkan generasi yang mampu berbaur dengan lingkungannya dan mampu hidup secara berdampingan dalam kelompok, disamping hal tersebut pendidikan dasar membekali peserta didik untuk mencapai kemampuan-kemampuan dasar seperti membaca, berhitung, menulis, serta kemampuan lain untuk mengembangkan aspek sosialnya seperti berkomunikasi, berpikir secara kritis, serta penguasaan dasar dalam mempelajari sainteks. Pendidikan dasar merupakan bekal yang dibawa oleh peserta didik untuk melanjutkan kejenjang sekolah lanjutan tingkat pertama.

\section{Kebijakan Standar Pembiayaan Pada Pendidikan Dasar}

Pada PP No. 32 Tahun 2013 menyebutkan tentang modal pembiayaan pendidikan yang akan digunakan selama satu periode dalam kurun waktu satu tahun, untuk mencapai penggunaan anggaran biaya pendidikan yang tepat dan efisien maka diperlukan analisis pendapatan dan penggunaan pembiayaan pendidikan secara tepat agar dapat mencapai tujuan yang telah direncanakan.standar pembiayaan pendidikan diatur dalam Peraturan Pemerintah pada Bab IX Pasal 62 Ayat (1) s/d (5), pada pasal I mengatur tentang besarnya anggaran dalam kegiatan pendidikan yang akan digunakan dalam satu periode tahunan, pada pasal 62 , berisi tentang modal atau biaya operasional maupun biaya personal. analisis pembiayaan pendidikan tidak hanya berpedoman pada aspek penggunaannya, disamping itu analis pembiayaan pendidikan dirumuskan dengan memperhatikan sumber-sumber pendapatannya serta berpedoman pada standarisasi dalam penggunaannya agar dapat mencapai tujuan sesuai dengan program yang telah direncanakan.

Berikut Standar Pembiayaan Pendidikan yang tercantum pada Bab IX: Pasal 62 berisi mengenai: (1) tiga komponen pendanaan pendidikan mencakup biaya modal/investasi, biaya yang digunakan dalam proses kegiatan pendidikan, serta biaya personal, (2) cakupan biaya modal terdiri dari pembiayaan yang menyangkut fasilitas sekolah, serta kegiatan pelatihan dan pengembangan pendidik dan tenaga kependidikan, dan modal kerja tetap, (3) setiap peserta didik diharuskan untuk mengeluarkan biaya yang akan digunakan dalam mengikuti proses kegiatan pembelajaran secara berkelanjutan (biaya personal), (4) biaya yang digunakan untuk pemberian gaji pendidik dan tenaga kependidikan disertai dengan segala tunjangan yang melekat, disamping hal tersebut biaya proses kegitan pendidikan/biaya operasional digunakan dalam mencukupi fasilitas sarana dan prasarana, konsumsi, pajak, dan lain sebagainya (biaya operasional) (Budaya, Malang, \& Nasional, 2006).

Kebijakan Standar Pembiayaan Pendidikan Dasar berpedoman pada juknispenggunan pembiayaan proses kegiatan sekolah, melalui program Bantuan Operasional Sekolah (BOS), pihak sekolah berkewajiban mengelola penggunaan dana dan biaya sesuai standar juknis BOS yang telah ditentukan. Pihak sekolah berwenang untuk mengambil suatu kebijakan atas penggunaan anggaran pembiayaan pendidikan sesuai dengan standarisasi yang telah ditentukan sesuai juknis. Permendikbud 8 Tahun 2020 tentang 
Petunjuk Teknis Bantuan Operasional Sekolah mengatur tentang: (1) selain SMP, SMK, SMA, pendidikan dasar termasuk dalam penerima bantuan operasional sekolah, (2) jumlah bantuan dana operasional sekolah disesuaikan dengan jumlah peserta didik dikalikan dengan besarnya satuan (3) untuk jenjang pendidikan dasar masing masing siswa memperoleh bantuan senilai Rp.900.000, (4) dana Bantuan Operasional Sekolah diperuntukkan sebagai biaya operasional sekolah yang berupa:pembiayaan dalam kegiatan persiapan pendaftaran peserta didik baru, proses kegiatan pembelajaran, kegiatan dalam evaluasi pembelajaran, kegiatan yang bersifat ekstrakurikuler, pelatihan dan pengembangan tenaga pendidik dan kependidikan, penyediaan fasilitas media pembelajaran, kelengkapan sarana dan prasarana sekolah, serta penggajian tenaga pendidik dan kependidikan dan lain sebagainya, berdasarkan hal tersebut, pihak sekolah berkewenangan mengelola kebijakan pembiayaan pendidikan dasar sesuai dengan standar yang tertuang dalam petunjuk teknis penggunaan anggaran pembiayaan, melalui standarisasi juknis yang ada diharapkan setiap satuan pendidikan dapat mengambil kebijakan anggaran pembiayaan yang tepat dan efisien demi tercapainya tujuan pendidikan yang diharapkan (Kurniady, 2011).

\section{KESIMPULAN}

Setiap satuan pendidikan membutuhkan pembiayaan untuk melaksanakan program kegiatannya baik program kegiatan sedang dijalankan, program yang akan dijalankan serta perencanaan program masa mendatang, pembiayaan pendidikan memiliki aturan dan standar minimum dalam penggunaanya, pembiayaan meliputi biaya modal, biaya dalam proses kegiatan pendidikan, dan biaya personal. Biaya pendidikan juga dapat diartikan sebagai segala pengeluaran yang digunakan untuk memperlancar kegiatan pendidikan baik berupa uang maupun bukan uang, pembiayaan pendidikan menjadi unsur penting dalam memperlancar proses kegiatan pendidikan, sehingga dalam penggunaanya perlu dipertimbangkan efisiensi dan efektifitasnya, analisis pembiayaan pendidikan tidak hanya berpedoman pada aspek penggunaannya, disamping itu analisis pembiayaan pendidikan dirumuskan dengan memperhatikan sumber-sumber pendapatannya serta berpedoman pada standar juknis anggaran pembiayaan agar dapat mencapai tujuan yang telah ditentukan.

Standar pengelolaan keuangan dan biaya pendidikan diatur dalam Peraturan Pemerintah pada Bab IX Pasal 62 Ayat (1) s/d (5), pada pasal I mengatur tentang besarnya anggaran dalam kegiatan pendidikan yang akan digunakan dalam kurun waktu satu periode tahunan, pada pasal 62, berisi tentang modal atau biaya operasional maupun biaya personal. Kebijakan standar pembiayaan pendidikan dasar berpedoman pada juknis penggunan pembiyaaan operasional sekolah, melalui program Bantuan Operasional Sekolah (BOS), pihak sekolah berkewajiban mengatur pendanaan serta berpedoman pada standar petunjuk teknis BOS yang telah ditentukan, pihak sekolah berwenang untuk menentukan kebijakan atas penggunaan anggaran pembiayaan pendidikan sesuai dengan standar yang telah ditentukan sesuai juknis. Melalui 
175 Analisis Kebijakan terkait Standar Pembiayaan pada Pendidikan Dasar-Aprima Vista, Ahmad Sabandi DOI: 10.31004/edukatif.v2i2.126

standar juknis yang ada diharapkan setiap satuan pendidikan dapat mengambil kebijakan anggaran pembiayaan yang tepat dan efisien demi tercapainya tujuan pendidikan yang diharapkan.

Setiap kegiatan Pendidikan tidak terlepas dari unsur pembiayaan, mutu pendidikan yang baik membutuhkan pembiayaan yang seimbang. Pembiayaan berperan penting dalam memperlancar kegiatan pendidikan, serta menjadi langkah dalam mencapai tujuan pendidikan. Lembaga sekolah merupakan sarana pendidikan yang memiliki kewenangan dalam menentukan kebijakan pengelolan pembiayaan, pengelolaan pembiayaan yang baik adalah pengelolaan yang mengacu pada juknis penggunaaannya, dengan demikian hendaknya setiap satuan pendidikan merujuk pada juknis standar pengeloaan pembiayaan demi mencapai efektifitas dan manfaat dari anggaran serta mencapai tujuan yang telah ditentukan.

\section{DAFTAR PUSTAKA}

(Raharjo, n.d.)Budaya, B., Malang, U. W., \& Nasional, S. P. (2006). Manajemen pembiayaan pendidikan pada sekolah dasar yang efektif. 42-59

Haris, H. A. (2016). Analysis on Policy Regulation of the Minister of National Education No 69 / 2009 About Funding Education Standards. (69), 365-374.

Kecamatan, D., \& Kabupaten, N. (n.d.). standar pengelolaan, Sekolah Dasar. 62-79.

Kurniady, D. A. (2011). Pengelolaan pembiayaan sekolah dasar di kabupaten bandung. Jurnal Penelitian Pendidikan, 12(1), 34-51. Retrieved from http://jurnal.upi.edu/file/4.pdf

Mózo, B. S. (2017). 済無No Title No Title. Journal of Chemical Information and Modeling, 53(9), 1689-1699.
https://doi.org/10.1017/CBO9781107415324.

004

Raharjo, S. B. (n.d.). Jurnal Penelitian dan Evaluasi Pendidikan. 511-532.

Shafratunnisa, F. (2015). Penerapan Prinsip Transparansi dan Akuntabilitas dalam Pengelolaan Keuangan kepada Stakeholders di SD Islam Binakheir.
Santoso, H. (n.d.). PENDIDIKAN KARAKTER UNTUK MENYIAPKAN GENERASI INDONESIA. 404-409.

Sekolah, D. A. N. M. (2016). Manajemen pembiayaan pendidikan, fasilitas pembelajaran, dan mutu sekolah. (2). 